\title{
What Future for the Anthropocene? A Biophysical Interpretation
}

\author{
Ugo Bardi ${ }^{1}$
}

Received: 29 February 2016/Accepted: 31 March 2016/Published online: 18 April 2016

(C) Springer International Publishing Switzerland 2016

\begin{abstract}
The Anthropocene is a proposed time subdivision of the earth's history correlated with the strong perturbation of the ecosystem created by human activity. Much debate is ongoing about what date should be considered as the start of the Anthropocene, but much less on how it will evolve in the future and what are its ultimate limits. It is argued here that the phenomena currently defining the Anthropocene will rapidly decline and disappear in times of the order of one century as a result of the irreversible dispersal of the thermodynamic potentials associated with fossil carbon. However, it is possible that, in the future, the human economic system may catalyze the dissipation of solar energy in forms other than photosynthesis, e.g., using solid-state photovoltaic devices. In this case, a strong human influence on the ecosystem may persist for much longer times, but in forms very different than the present ones.
\end{abstract}

Keywords Anthropocene $\cdot$ Dissipative systems $\cdot$ Limits to growth - Photosynthesis - Renewable energy .

Photovoltaics

The history of the earth system is normally described in terms of a series of time subdivisions defined by discrete (or "punctuated") stratigraphic changes in the geological record, mainly in terms of biotic composition (Aunger $2007 \mathrm{a}, \mathrm{b}$ ). The most recent of these subdivisions is the proposed "Anthropocene," a term related to the strong

Ugo Bardi

ugo.bardi@unifi.it

1 Dipartimento di Scienze della Terra, Polo Scientifico di Sesto Fiorentino, Università di Firenze, 50019 Sesto Fiorentino, FI, Italy perturbation of the ecosystem created by human activity. The starting date of the Anthropocene is not yet officially established, but it is normally identified with the start of the large-scale combustion of fossil carbon compounds stored in the earth's crust ("fossil fuels") on the part of the human industrial system. In this case, it could be located at some moment during the eighteenth century CE (Crutzen 2002; Lewis and Maslin 2015). Alternative proposals would place the start of the Anthropocene with the development of agriculture (Ruddiman 2013; Ruddiman et al. 2015), or of nuclear fission technologies (Zalasiewicz et al. 2015). However, it is clear that the human influence on the earth system has enormously increased with the use of fossil fuels and this influence still remains mainly linked to fossil fuels (Raupach and Canadell 2010). So, we may ask the question of what the evolution of the Anthropocene could be as a function of the decreasing availability of fossil carbon compounds. Will the Anthropocene decline and the earth system return to conditions similar to the previous geologic subdivision, the Holocene? Or will the human perturbation continue, but in very different forms, e.g., using solid-state transduction devices to collect solar energy? These are the questions examined in the present paper.

The earth system is a nonequilibrium system whose behavior is determined by the flows of energy it receives. This kind of system tends to act as energy transducer and to dissipate the available energy potentials at the fastest possible rate (Sharma and Annila 2007; Kaila and Annila 2008); a property that can also be understood in terms of the principle known as "maximum entropy production" (Kleidon 2004; Kleidon et al. 2010; Martyushev and Seleznev 2006). Nonequilibrium systems tend to attain the property called "homeostasis" if the potentials they dissipate remain approximately constant (Kleidon 2004). In the 
case of the earth system, by far, the largest flow of energy comes from the sun. It is approximately constant (Iqbal 1983), except for very long timescales, since it gradually increases by a factor of about $10 \%$ per billion years (Schroeder and Connon Smith 2008). Therefore, the earth's ecosystem would be expected to reach and maintain homeostatic conditions over timescales of the order of hundreds of millions of years. However, this does not happen because of geological perturbations that generate the punctuated transitions observed in the stratigraphic record.

The flow of geothermal energy to the earth surface is about two orders of magnitude smaller than that of the solar energy (Davies and Davies 2010), and it is known to change very slowly over geological timescales (Korenaga 2008). However, it is subjected to punctuated changes in the form of volcanic eruptions and tectonic movements. These perturbations are the main cause of the transitions that generate geological time subdivisions. For instance, it is known that during the Phanerozoic period a strong correlation can be observed between large basaltic eruptions (known as "large igneous provinces," LIPs) and mass extinctions, in turn often associated with geological time boundaries (Kidder and Worsley 2010; Wignall 2001; Bond and Wignall 2014). Extraterrestrial factors, such as asteroidal impacts, have also been claimed to generate discontinuities during the Phanerozoic, but their effect may have been overestimated (Archibald 2014; Bond and Wignall 2014).

A further factor that may create discontinuities in the sedimentary record is linked to evolutionary changes in the biosphere, of the kind defined as "revolutions" (Szathmáry and Smith 1995; Kleidon 2004), where the ecosystem "learns" how to increase the rate of dissipation of the available potentials (Kaila and Annila 2008). It has been estimated that the amount of solar energy processed by terrestrial organisms has increased by a factor of about one thousand over a time span of about 3 billion years (Lenton and Watson 2011, p. 49). Changes in this capability may lead to radical changes in the ecosystem record; for instance, the "great oxygenation event" (GOE) that occurred at ca. $2.5 \mathrm{Ga}$ ago may be related to the Archean/ Proterozoic boundary (Gargaud et al. 2011).

The transition that generated the Anthropocene is also related to a discontinuity in the energy dissipation rate of the ecosystem. This discontinuity appeared when the ecosystem (more exactly, the "homo sapiens" species) learned how to dissipate the energy potential of the carbon compounds stored in the earth's crust, mainly in the form of crude oil, natural gas, and coal). These compounds had slowly accumulated as the result of the sedimentation of organic matter mainly over the Phanerozoic era, that is over a timescale of the order of hundreds of millions of years (Raupach and
Canadell 2010). The rate of energy dissipation of this fossil potential, at present, can be estimated in terms of the "primary energy" use per unit time at the input of the human economic system. In 2013, this amount corresponded to ca. 18 TW (IEA 2015). Of this power, about $86 \%$ (or ca. 15 TW) were produced by the combustion of fossil carbon compounds. This is a small amount in comparison with the average total flow of the solar energy that reaches the earth's surface, estimated as 89,000 TW (Tsao et al. 2006) or 87,000 TW (Szargut 2003). However, the thermal energy directly produced by combustion is just a trigger for other, more important effects that have created the Anthropocene. Among these, we may list as the dispersion of large amounts of heavy metals and radioactive isotopes in the ecosphere, the extended paving of large surface areas by inorganic compounds (Schneider et al. 2009), the destruction of a large fraction of the continental shelf surface by the practice known as "bottom trawling" (Zalasiewicz et al. 2011), and more. The most important indirect effect on the ecosystem of the combustion of fossil carbon is the emission of greenhouse gases as combustion products, mainly carbon dioxide, $\mathrm{CO}_{2}$, (Stocker et al. 2013). The thermal forcing generated by $\mathrm{CO}_{2}$ alone can be calculated as approximately $900 \mathrm{TW}$, or about $1 \%$ of the solar radiative effect (Zhang and Caldeira 2015), hence a nonnegligible effect that generates an already detectable greenhouse warming of the atmosphere. This warming, together with other effects such as oceanic acidification, has the potential of deeply changing the ecosystem in the same way as, in ancient times, LIPs have generated mass extinctions (Wignall 2005; Bond and Wignall 2014).

Greenhouse gases created by the combustion of fossil fuels have been accumulating in the atmosphere since the beginning of the industrial age. However, this process must eventually stop since fossil carbon compounds exist in limited amounts inside the earth's crust. The total mass of fossil carbon is estimated as ca. $1.5 \times 10^{16}$. $t\left(1.25 \times 10^{21} \mathrm{~mol} \mathrm{C}\right)$, mainly in the form of the family of compounds known as "kerogen" (Falkowski et al. 2000). Considering that the present combustion rate of fossil carbon is reported to be about $9.2 \times 10^{+9} t$ per year (Le Quéré et al. 2014), one could conclude that, theoretically, it could continue for more than one million years. But this is evidently impossible, if nothing else because the oxygen would run out much earlier (the amount of gaseous oxygen in the atmosphere is estimated as ca $1.2 \times 10^{15} t$, or $3.7 \times 10^{19} \mathrm{~mol} \mathrm{O}_{2}$ ) (Canfield 2005). However, a much more drastic limitation derives from the fact that not all the fossil carbon present in the earth's crust is "burnable" carbon, that is, carbon that is likely to be burned by the human industrial system.

The quantity of burnable carbon is normally assessed on the basis of factors related to the human economy, that is, in terms of the carbon compounds whose cost of extraction 
can provide a profit at the current prices of energy. A comprehensive estimate based on this concept (Rogner 1997) indicated that the known fossil reserves could theoretically sustain the present consumption rate for about one century and a half, even though "non conventional" resources could extend this period. However, this kind of estimate suffers from fundamental uncertainties since it is impossible to predict the prices of energy a century from now (and even for much shorter time spans). So, a more reliable estimate should be based on thermodynamic factors.

The combination of atmospheric oxygen with fossil carbon is a chemical reaction, and as such, it needs to overcome a kinetic barrier of the kind normally defined as "activation energy." This energy determines the reaction rate; the higher the barrier, the slower the rate. In the case of the combustion of fossil fuels, the barrier is generated by the fact that most fossil carbon is stored underground, not in direct contact with atmospheric oxygen. As a result, during the Phanerozoic period, sedimentation has accumulated carbon faster than it has been removed by natural oxidation or combustion, despite the latter reactions being thermodynamically favored. It is also well known that the activation energy of a chemical reaction can be lowered by a catalyst and that, as a consequence, the reaction rate can be accelerated. This is the role played today by the human economy: a catalyst that enormously accelerated the oxidation rate of fossil carbon. In addition, the combustion of fossil carbon can be defined as an "autocatalytic" reaction, in the sense that it generates structures that accelerate the reaction rate. This is typical of many chemical reactions and physical processes which tend to create "dissipative structures," as described for the first time by Prigogine (1967, 1968).

The dissipation structures created by the dissipation of the fossil fuel potentials can be defined with the generic name of "industrial system." Burning fossil fuels generate the exergy needed to create industrial structures which, in turn, are used to extract more fossil fuels and burn them. In this sense, the human industrial system can be seen as a metabolic system, akin to biological ones (Malhi 2014). The structures of this nonbiological metabolic system can be examined in light of concepts such as "net energy" (Odum 1973) defined as the exergy generated by the transduction of an energy stock into another form of energy stock. Another, similar concept is "energy return for energy invested" (EROI or EROEI), first defined in 1986 (Hall et al. 1986) [see also (Hall et al. 2014)]. EROEI is defined as the ratio of the exergy obtained by means of a certain dissipation structure to the amount of exergy necessary to create and maintain the structure. As an example related to the human economy, coal simply burned in air generates no exergy and is rapidly dissipated without creating dissipation structures existing in a long-term homeostatic condition. Instead, coal burned in a steam engine (a dissipation structure) generates mechanical energy (exergy) that can be used to manufacture equipment to drill, excavate, lift, and transport more coal, and also to maintain the steam engine and manufacture new ones. If the EROEI associated with a dissipation process is larger than one, the excess can be used to replicate the process in new structures. On a large scale, this process can create the complex system that we call the "industrial society." The growth of the human civilization as we know it today, and the whole Anthropocene, can be seen as the effect of the relatively large EROEI, of the order of 20-30 and perhaps more, associated with the combustion of fossil carbon compounds (Lambert et al. 2014). On the contrary, an EROEI smaller than 1 (or, equivalently, a net energy smaller than zero) implies that the process cannot be selfsustaining, that is, the dissipation structures are bound to disappear.

A peculiarity of the dissipation of potentials associated with fossil hydrocarbons is that the system cannot attain homeostasis. It has been recognized from the times of Jevons (1866) that the mineral industry extracts first the "high grade" resources, defined as the most concentrated ores available. In the case of fossil fuels, the high-grade resources are those which produce the maximum exergy for the minimum requirement in exergy for extraction, that is, the maximum EROEI. As the stock of these resources is exhausted, the industry moves to lower quality resources (e.g., deeper or containing contaminants) which require more energy expensive extraction structures. This leads to a progressive decline of the EROEI associated with fossil potentials, although the decline can be slowed down, or even partly reversed, by technological factors and scale factors. For instance, Hall et al. (2014) show that the EROEI of oil extraction in the USA peaked at around 30 in the 1960s, to decline to values lower than 20 at present. A further factor to be taken into account is called "pollution," which accelerates the degradation of the accumulated capital stock and hence reduces the EROEI of the system as it requires more exergy for its maintenance (Meadows et al. 1972).

Only a small fraction of the crustal fossil carbon compounds can provide an EROEI $>1$, and an even smaller one can provide the large EROEIs that have created the industrial civilization (Hall et al. 2009; Zencey 2013). Therefore, we can expect that the progressive reduction in the average EROEI values for fossil fuels will lead to a slowdown of the combustion reaction. Various models describe this phenomenon: Historically, the first one goes back to Jevons (1866), and later on, the concept was taken up from an empirical viewpoint by Hubbert (1956), and later on quantified by several studies, often based on 
system dynamics (Forrester 1971; Meadows et al. 1972, 2004; Bardi and Lavacchi 2009). All these studies show that the cycle of exploitation of a finite energy resource should follow a "bell shaped" curve, although not necessarily a symmetric one. A large number of studies have examined the cycle of exploitation of fossil hydrocarbons with the objective of making quantitative predictions [see, e.g. (Maggio and Cacciola 2012; Guseo 2011; Campbell and Laherrere 1998; Zittel et al. 2013; Turner 2008; Bardi 2014)]. The results are, obviously, only estimates, but the general conclusion is that the carbon-generated power "pulse" of the Anthropocene is destined fade away in times of the order of one century. The pulse was already detected in the "base case" scenario of the study titled "The Limits to Growth" (Meadows et al. 1972), even thought at that time it was not recognized as such. In this study, confirmed by later works (Meadows et al. 2004), the cycle of the industrial civilization was calculated on the basis of the available natural resources and it was found to correspond to a nonsymmetric, bell-shaped curve for the global industrial production. The curve shows a maximum during the first two decades of the twenty-first century, to decline rapidly afterward and fade out with the end of the century. This curve can be understood as representing the "Anthropocene cycle."

So, when the geological estimates are combined with a thermodynamic analysis, the result is that the active phase of the Anthropocene is destined to last only a relatively short time for a geological time subdivision, a few centuries and no more. The stratigraphic markers that would indicate the end of this phase could be several and would be mainly related to artifacts and materials related to the human civilization. Without the exergy produced by fossil fuels, it is likely that most of the presently ongoing industrial activities would stop. This would leave a welldefined boundary for a sedimentary layer that would contain, among others, heavy metals such as mercury, lead, chromium, and others. It would also contain long-lasting artificially created radioactive isotopes, some of which have half-lives of several million years (e.g., 2.1 million years for neptunium 237) (Loubergé et al. 2002). Identifying this boundary would be easy for future geologists, although, of course, we cannot be sure that there will be any.

Even assuming the complete demise of the human industrial system, a long tail of effects on the ecosystem will follow the active phase of the Anthropocene. A fraction of the carbon dioxide emitted during that phase is expected to remain in the earth's atmosphere for several tens of thousands of years, even hundreds of thousands (Archer and Caldeira 2009). It is not known how long the carbon dioxide will remain in other crustal reservoirs, such as in the oceans but, in order to see the combustion process completely reversed, we should wait for new crustal carbon reservoirs to be reformed, mainly kerogen, but also coal, gas, and oil. Hundreds of thousands of years, at least, may be required for this process to complete (Archer 2010). So, considering that the earth system is in continuous evolution, it may never return to exactly the same conditions of the ages that have preceded the Anthropocene. The future characteristics of the earth's ecosystem are obviously difficult to determine. It appears that the earth's climate might not have dropped into a new ice age phase even without the human-related $\mathrm{CO}_{2}$ perturbation (Ganopolski et al. 2016). Factoring in the increase of $\mathrm{CO}_{2}$ concentration, the climate system could remain in an hot "interglacial" state for at least 10,000 years in the future (Berger et al. 2003) and probably for much longer times, of the order of thirty thousand years or more (Herrero et al. 2014) before slowly returning to the cycles of ice ages and interglacials that characterized the Pleistocene. The human perturbation might even lead to truly catastrophic and irreversible changes (Hansen 2007). In any case, the gradual increase in the intensity of the solar irradiation will eventually lead to the disappearance of the vertebrates in some 800 million years in the future and, eventually, to the complete sterilization of the planet one billion and a half years in the future (Franck et al. 2006; Schroeder and Connon Smith 2008).

Assuming that humans will still exist during the postAnthropocene tail, they would not have access to fossil fuels. As a consequence, their impact on the ecosystem would be mainly related to agricultural activities and, therefore, small in comparison with the present one, although likely not negligible, as it has been in the past (Ruddiman 2013; Mysak 2008). However, we should also take into account that fossil carbon is not the only energy potential available to the human industrial system. Fissile nuclei (such as uranium and thorium) can also generate potentials that can be dissipated. However, this potential is limited in extent and cannot be reformed by Earth-based processes. Barring radical new developments, depletion of mineral uranium and thorium is expected to prevent this process to play an important role in the future (Zittel et al. 2013). Nuclear fusion of light nuclei may also be considered but, so far, there is no evidence that the potential associated with the fusion of deuterium nuclei can generate an EROEI sufficient to maintain an industrial civilization, or even to maintain itself. Other potentials exist at the earth's surface in the form of geothermal energy (Davies and Davies 2010) and tidal energy (Munk and Wunsch 1998); both are, however, limited in extent and unlikely to be able to provide the same flow of exergy generated today by fossil carbon compounds.

There remains the possibility of processing the flow of solar energy at the earth surface that, as mentioned earlier 
on, is large $[89,000$ TW (Tsao et al. 2006) or 87,000 TW (Szargut 2003)]. Note also that the atmospheric circulation generated by the sun's irradiation produces some $1000 \mathrm{TW}$ of kinetic energy (Tsao et al. 2006). These flows are orders of magnitude larger than the flow of primary energy associated with the Anthropocene (ca. 17 TW). Of course, as discussed earlier on, the capability of a transduction system to create complex structures depends on the EROEI of the process. This EROEI is difficult to evaluate with certainty, because of the continuous evolution of the technologies. We can say that all the recent studies on photovoltaic systems report EROEIs larger than one for the production of electric power by means of photovoltaic devices (Rydh and Sandén 2005; Richards and Watt 2007; Weißbach et al. 2013; Bekkelund 2013; Carbajales-Dale et al. 2015; Bhandari et al. 2015) even though some studies report smaller values than the average reported ones (Prieto and Hall 2011). In most cases, the EROEI of PV systems seems to be smaller than that of fossil burning systems, but, in some cases, it is reported to be larger (Raugei et al. 2012), with even larger values being reported for CSP (Montgomery 2009; Chu 2011). Overall, values of the EROEI of the order of 5-10 for direct transduction of solar energy can be considered as reasonable estimates (Green and Emery 2010). Even larger values of the EROEI are reported for wind energy plants (Kubiszewski et al. 2010). These values may increase as the result of technological developments, but also decline facing the progressive occupation of the best sites for the plants and to the increasing energy costs related to the depletion of the minerals needed to build the plants.

The long-term sustainability of solar and wind technologies is a difficult subject to evaluate. The current photovoltaic and wind technologies may use, but do not necessarily need, rare elements that could face near-term exhaustion problems (García-Olivares et al. 2012). Photovoltaic cells are manufactured using mainly silicon and aluminum, both common elements in the earth's crust. Wind turbines use mainly steel, aluminum, and concrete, but the current technology uses rare earths for the generation of strong magnetic fields. Even though rare earths are not so rare as the name seems to imply, their use in wind systems makes their long-term sustainability problematic. Rare earth magnets could be, however, replaced by iron magnets at the cost of a reduced performance or by electromagnetic or superconducting magnet systems (Terao et al. 2012). Then, all these technologies generate electric current, which requires an infrastructure for its transport and storage; in turn requiring specific mineral resources (e.g., lithium for the current generation of batteries). However, the energy system may be adapted and transformed in ways that reduce the need of storage (Barnhart and Benson 2013; Barnhart et al. 2013). Recycling can also reduce the problem of mineral availability, and some studies have reported that the materials used for solar cells can be recycled at rates of $99.99 \%$ (Fthenakis 2009). However, no practical recycling process can reach $100 \%$ efficiency. In the end, we cannot determine, at present, if the energy requirements for minerals could lower the EROEI of future renewable technologies to the point that they would not be self-sufficient any longer. However, taking into account the probable future improvements for these technologies, there do not appear to exist fundamental barriers to "close the cycle" and to use the exergy generated by human-made solar-powered devices (in particular PV systems) to recycle the systems for a very long time.

Various estimates exist on the ultimate limits of energy generation from photovoltaic systems. The "technical potential" in terms of solar energy production in the USA alone is estimated as more than $150 \mathrm{TW}$ (Lopez et al. 2012). According to the data reported in (Liu et al. 2009), about $1 / 5$ of the area of the Sahara desert (2 million square $\mathrm{km}$ ) could generate around $50 \mathrm{TW}$ at an overall PV panel area conversion efficiency of $10 \%$. Summing up similar fractions of the areas of major deserts, PV plants (or CSP ones) could generate around 500-1000 TW, possibly more than that, without significantly impacting on agricultural land. The contribution of wind energy has been estimated to be no more than 1 TW (de Castro et al. 2011) in some assumptions that have been criticized in (GarciaOlivares 2016) Other calculations indicate that wind could generate as much as about $80 \mathrm{TW}$, (Jacobson and Archer 2012), or somewhat smaller values (Miller et al. 2011). Overall, these values are much larger than those associated with the combustion of fossil fuels, with the added advantage that renewables such as PV and wind produce higher quality energy in the form of electric power.

From these data, we can conclude that the transduction of the solar energy flow by means of inorganic devices could represent a future new metabolic "revolution" of the kind described by (Szathmáry and Smith 1995). (Lenton and Watson 2011) that could bootstrap the ecosphere to a new and higher level of transduction. It is too early to say if such a transition is possible, but, if it were to take place at its maximum potential, its effects could lead to transformations larger than those associated with the Anthropocene as it is currently understood. These effects are hard to predict at present, but they may involve changes in the planetary albedo, in the weather patterns, and in the general management of the land surface. Overall, the effect might be considered as a new geological transition. As these effects would be mainly associated with solid-state devices (PV cells), perhaps we need a different term than "Anthropocene" to describe this new phase of the earth's history. The term "Stereocene" (the age of solid-state 
devices) could be suitable to describe a new stage of the earth system in which humans could have access to truly gigantic amounts of useful energy, without necessarily perturbing the ecosystem in the highly destructive ways that have been the consequence of the use of fossil fuels during the past few centuries.

\section{References}

Archer D (2010) The long thaw: how humans are changing the next 100,000 years of earth's climate. (eBook and Paperback). Princeton University Press, Princeton

Archer CL, Caldeira K (2009) Global assessment of high-altitude wind power. Energies 2:307-319. doi:10.3390/en20200307

Archibald JD (2014) What the dinosaur record says about extinction scenarios. Geol Soc Am Spec Pap 505:213-224. doi:10.1130/ 2014.2505(10)

Aunger R (2007a) Major transitions in "big" history. Technol Forecast Soc Change 74:1137-1163. doi:10.1016/j.techfore.2007.01. 006

Aunger R (2007b) A rigorous periodization of "big" history. Technol Forecast Soc Change 74:1164-1178. doi:10.1016/j.techfore. 2007.01.007

Bardi U (2014) The mineral question: how energy and technology will determine the future of mining. Front Energy Syst Policy. doi:10.3389/fenrg.2013.00009

Bardi U, Lavacchi A (2009) A simple interpretation of Hubbert's model of resource exploitation. Energies 2:646-661. doi:10.3390/en20300646

Barnhart CJ, Benson SM (2013) On the importance of reducing the energetic and material demands of electrical energy storage. Energy Environ Sci 6:1083. doi:10.1039/c3ee24040a

Barnhart CJ, Dale M, Brandt AR, Benson SM (2013) The energetic implications of curtailing versus storing solar- and wind-generated electricity. Energy Environ Sci 6:2804. doi:10.1039/c3ee41973h

Bekkelund K (2013) A comparative life cycle assessment of PV solar systems. Norwegian University of Science and Technology, NTNU-Trondheim

Berger A, Loutre MF, Crucifix M (2003) The Earth's climate in the next hundred thousand years (100 kyr). Surv Geophys 24:117138. doi:10.1023/A:1023233702670

Bhandari B, Lee K-T, Lee G-Y et al (2015) Optimization of hybrid renewable energy power systems: a review. Int J Precis Eng Manuf Technol 2:99-112. doi:10.1007/s40684-015-0013-Z

Bond D, Wignall P (2014) Large igneous provinces and mass extinctions: an update. Geol Soc Am Spec Pap 505:29-55. doi:10.1130/2014.2505(02)

Campbell CJ, Laherrere JF (1998) The end of cheap oil. Sci Am $80-86$

Canfield DE (2005) The early history of atmospheric oxygen: homage to Robert M Garrels. Annu Rev Earth Planet Sci 33:1-36. doi:10. 1146/annurev.earth.33.092203.122711

Carbajales-Dale M, Raugei M, Fthenakis V, Barnhart C (2015) Energy return on investment (EROI) of solar PV: an attempt at reconciliation [point of view]. Proc IEEE 103:995-999. doi:10. 1109/JPROC.2015.2438471

Chu Y (2011) Review and comparison of different solar energy technologies. Report by GENI (Global Energy Research Institute). http://www.geni.org/globalenergy/research/review-andcomparison-of-solar-technologies/Review-and-Comparison-ofDifferent-Solar-Technologies.pdf. Accessed 12 Apr 2016

Crutzen PJ (2002) Geology of mankind. Nature 415:23. doi:10.1038/ $415023 \mathrm{a}$
Davies JH, Davies DR (2010) Earth's surface heat flux. SolidEarth 1:5-24. doi:10.5194/se-1-5-2010

de Castro C, Mediavilla M, Miguel LJ, Frechoso F (2011) Global wind power potential: physical and technological limits. Energy Policy 39:6677-6682. doi:10.1016/j.enpol.2011.06.027

Falkowski P, Scholes RJ, Boyle E et al (2000) The global carbon cycle: a test of our knowledge of earth as a system. Science 290(80):291-296. doi:10.1126/science.290.5490.291

Forrester J (1971) World dynamics. Wright-Allen Press, Cambridge, Massachusetts

Franck S, Bounama C, von Bloh W (2006) Causes and timing of future biosphere extinctions. Biogeosciences 3:85-92. doi:10. 5194/bg-3-85-2006

Fthenakis V (2009) Sustainability of photovoltaics: the case for thinfilm solar cells. Renew Sustain Energy Rev 13:2746-2750. doi:10.1016/j.rser.2009.05.001

Ganopolski A, Winkelmann R, Schellnhuber HJ (2016) Critical insolation- $-\mathrm{CO}_{2}$ relation for diagnosing past and future glacial inception. Nature 529:200-203. doi:10.1038/nature16494

Garcia-Olivares A (2016) Energy for a sustainable post-carbon society

García-Olivares A, Ballabrera-Poy J, García-Ladona E, Turiel A (2012) A global renewable mix with proven technologies and common materials. Energy Policy 41:561-574. doi:10.1016/j. enpol.2011.11.018

Gargaud M, Amils R, Quintanilla JC et al (eds) (2011) Encyclopedia of Astrobiology. Springer, Berlin Heidelberg, Berlin, Heidelberg

Green M, Emery K (2010) Solar cell efficiency tables (version 35). Prog Photovoltaics 18:144-150. doi:10.1002/pip.974

Guseo R (2011) Worldwide cheap and heavy oil productions: a longterm energy model. Energy Policy 39:5572-5577. doi:10.1016/j. enpol.2011.04.060

Hall CA, Cleveland CJ, Kaufmann R (1986) Energy and resource quality: the ecology of the economic process. Wiley Interscience, New York

Hall C, Balogh S, Murphy D (2009) What is the minimum EROI that a sustainable society must have? Energies $2: 25-47$. doi:10.3390/ en20100025

Hall CAS, Lambert JG, Balogh SB (2014) EROI of different fuels and the implications for society. Energy Policy 64:141-152. doi:10. 1016/j.enpol.2013.05.049

Hansen J (2007) Climate catastrophe. New Sci 195:30-34. doi:10. 1016/S0262-4079(07)61903-4

Herrero C, Garcia-Olivares A, Pelegrì JR (2014) Impact of Anthropogenic $\mathrm{CO}_{2}$ on the next glacial cycle. Clim Change 122:283-298

Hubbert MK (1956) Nuclear energy and the fossil fuels. In: Spring meeting of the southern district division of production American Petroleum Institute. American Petroleum Institute, Sant Antonio, Texas

IEA (2015) Key World Energy Statistics 2015, p 38. http://www.iea. org/publications/freepublications/publication/KeyWorld_Statistics_ 2015.pdf. Accessed 19 Apr 2016

IPCC 2013 (2013) Summary for policymakers. In: Stocker TF, Qin D, Plattner G-K, et al (eds) Climate change 2013: the physical science basis. Contribution of working group I to the fifth assessment report of the intergovernmental panel on climate change. Cambridge University Press, Cambridge, UK and New York, USA

Iqbal M (1983) An introduction to solar radiation. Academic Press Canada, New York

Jacobson MZ, Archer CL (2012) Saturation wind power potential and its implications for wind energy. Proc Natl Acad Sci U S A 109:15679-15684. doi:10.1073/pnas.1208993109

Jevons WS (1866) The coal question, 2nd revised edition. Macmillan and $\mathrm{Co}$ 
Kaila VR, Annila A (2008) Natural selection for least action. Proc R Soc A Math Phys Eng Sci 464:3055-3070. doi:10.1098/rspa. 2008.0178

Kidder D, Worsley T (2010) Phanerozoic large igneous provinces (LIPs), HEATT (haline euxinic acidic thermal transgression) episodes, and mass extinctions. Palaeogeogr Palaeoclimatol Palaeoecol 295:162-191. doi:10.1016/j.palaeo.2010.05.036

Kleidon A (2004) Beyond Gaia: thermodynamics of life and Earth system functioning. Clim Change 66:271-319. doi:10.1023/B: CLIM.0000044616.34867.ec

Kleidon A, Malhi Y, Cox PM (2010) Maximum entropy production in environmental and ecological systems. Philos Trans R Soc Lond B Biol Sci 365:1297-1302. doi:10.1098/rstb.2010.0018

Korenaga J (2008) Urey ratio and the structure and evolution of Earth's mantle. Rev Geophys 46:2007. doi:10.1029/2007RG000241

Kubiszewski I, Cleveland C, Endres P (2010) Meta-analysis of net energy return for wind power systems. Renew Energy 35:218-225

Lambert JG, Hall CAS, Balogh S et al (2014) Energy, EROI and quality of life. Energy Policy 64:153-167. doi:10.1016/j.enpol.2013.07.001

Le Quéré C, Peters GP, Andres RJ et al (2014) Global carbon budget 2013. Earth Syst Sci Data 6:235-263. doi:10.5194/essd-6-2352014

Lenton T, Watson A (2011) Revolutions that made the Earth. Oxford University Press, Oxford

Lewis SL, Maslin MA (2015) Defining the Anthropocene. Nature 519:171-180. doi:10.1038/nature 14258

Liu Q, Yu G, Liu JJ (2009) Solar radiation as large-scale resource for energy-short World. Energy Environ 20(3):319-329

Lopez A, Roberts B, Heimiller D, et al (2012) U.S. renewable energy technical potentials: a GIS-based analysis

Loubergé H, Villeneuve S, Chesney M (2002) Long-term risk management of nuclear waste: a real options approach. J Econ Dyn Control 27:157-180. doi:10.1016/S0165-1889(01)00058-6

Maggio G, Cacciola G (2012) When will oil, natural gas, and coal peak? Fuel 98:111-123. doi:10.1016/j.fuel.2012.03.021

Malhi Y (2014) The metabolism of a human-dominated planet. In: Goldin I (ed) Is the planet full?. Oxford University Press, Oxford, pp 142-164

Martyushev LM, Seleznev VD (2006) Maximum entropy production principle in physics, chemistry and biology. Phys Rep 426:1-45. doi:10.1016/j.physrep.2005.12.001

Meadows DH, Meadows DL, Randers J, Bherens W III (1972) The limits to growth. Universe Books, New York

Meadows DH, Randers J, Meadows DL (2004) Limits to growth: the 30 year update. Chelsea Green, White River Junction

Miller LM, Gans F, Kleidon A (2011) Estimating maximum global land surface wind power extractability and associated climatic consequences. Earth Syst Dyn 2:1-12. doi:10.5194/esd-2-1-2011

Montgomery Z (2009) Environmental impact study: CSP vs. CdTe thin film photovoltaics. Duke University, Nicholas School of the Environment and Earth Sciences, Master Thesis. http://hdl. handle.net/10161/1551. Accessed 12 Apr 2015

Munk W, Wunsch C (1998) Abyssal recipes II: energetics of tidal and wind mixing. Deep Sea Res Part I Oceanogr Res Pap 45:1977-2010. doi:10.1016/S0967-0637(98)00070-3

Mysak LA (2008) Glacial inceptions: past and future. Atmos Ocean 46:317-341. doi:10.3137/ao.460303

Odum HT (1973) Energy, ecology, and economics. Ambio 2:220-227

Prieto P, Hall C (2011) Spain's photovoltaic revolution: the energy return on investment. Springer, New York

Prigogine I (1967) On symmetry-breaking instabilities in dissipative systems. J Chem Phys 46:3542. doi:10.1063/1.1841255

Prigogine I (1968) Symmetry breaking instabilities in dissipative systems II. J Chem Phys 48:1695. doi:10.1063/1.1668896

Raugei M, Fullana-i-Palmer P, Fthenakis V (2012) The energy return on energy investment (EROI) of photovoltaics: methodology and comparisons with fossil fuel life cycles. Energy Policy 45:576-582. doi:10.1016/j.enpol.2012.03.008

Raupach MR, Canadell JG (2010) Carbon and the Anthropocene. Curr Opin Environ Sustain 2:210-218. doi:10.1016/j.cosust. 2010.04.003

Richards BS, Watt ME (2007) Permanently dispelling a myth of photovoltaics via the adoption of a new net energy indicator. Renew Sustain Energy Rev 11:162-172. doi:10.1016/j.rser.2004. 09.015

Rogner H-H (1997) An assessment of World hydrocarbon resources. Annu Rev Energy Environ 22:217-262. doi:10.1146/annurev. energy.22.1.217

Ruddiman WF (2013) The Anthropocene. Annu Rev Earth Planet Sci 41:45-68. doi:10.1146/annurev-earth-050212-123944

Ruddiman WF, Ellis EC, Kaplan JO, Fuller DQ (2015) Defining the epoch we live in. Science 348(80):38-39. doi:10.1126/science. aaa7297

Rydh CJ, Sandén BA (2005) Energy analysis of batteries in photovoltaic systems. Part II: energy return factors and overall battery efficiencies. Energy Convers Manag 46:1980-2000. doi:10.1016/j.enconman.2004.10.004

Schneider A, Friedl MA, Potere D (2009) A new map of global urban extent from MODIS satellite data. Environ Res Lett 4(4):044003

Schroeder K-P, Connon Smith R (2008) Distant future of the Sun and Earth revisited. Mon Not R Astron Soc 386:155-163. doi:10. 1111/j.1365-2966.2008.13022.x

Sharma V, Annila A (2007) Natural process-natural selection. Biophys Chem 127:123-128. doi:10.1016/j.bpc.2007.01.005

Szargut JT (2003) Anthropogenic and natural exergy losses (exergy balance of the Earth's surface and atmosphere). Energy 28:1047-1054. doi:10.1016/S0360-5442(03)00089-6

Szathmáry E, Smith JM (1995) The major evolutionary transitions. Nature 374:227-232. doi:10.1038/374227a0

Terao Y, Sekino M, Ohsaki H (2012) Electromagnetic design of $10 \mathrm{MW}$ class fully superconducting wind turbine generators. Appl Supercond IEEE. doi:10.1109/TASC.2011.2177628

Tsao J, Lewis N, Crabtree G (2006) Solar FAQs. In: US Department Energy. http://rogachev.dyndns-at-home.com:8080/Copy/Engi neering/SolarFAQs.pdf. Accessed 5 Jan 2015

Turner G (2008) A comparison of the limits to growth with 30 years of reality. Glob Environ Change 18:397-411. doi:10.1016/j. gloenvcha.2008.05.001

Weißbach D, Ruprecht G, Huke A et al (2013) Energy intensities, EROIs (energy returned on invested), and energy payback times of electricity generating power plants. Energy 52:210-221. doi:10.1016/j.energy.2013.01.029

Wignall PB (2001) Large igneous provinces and mass extinctions. Earth Sci Rev 53:1-33. doi:10.1016/S0012-8252(00)00037-4

Wignall P (2005) The link between large igneous province eruptions and mass extinctions. Elements 1:293-297. doi:10.2113/gsele ments.1.5.293

Zalasiewicz J, Williams M, Fortey R et al (2011) Stratigraphy of the Anthropocene. Philos Trans A Math Phys Eng Sci 369:10361055. doi:10.1098/rsta.2010.0315

Zalasiewicz J, Waters CN, Williams M et al (2015) When did the Anthropocene begin?. Quat Int, A mid-twentieth century boundary level is stratigraphically optimal. doi:10.1016/j.quaint.2014. 11.045

Zencey E (2013) Energy as master resource. In: Assadourian E, Prugh $\mathrm{T}$ (eds) State of the World 2013. Island Press/Center for Resource Economics, Washington, Covelo, London, pp. 73-83

Zhang X, Caldeira K (2015) Time scales and ratios of climate forcing due to thermal versus carbon dioxide emissions from fossil fuels. Geophys Res Lett. doi:10.1002/2015GL063514

Zittel W, Zerhusen J, Zerta M, et al (2013) Fossil and nuclear fuels: the supply outlook 